\title{
Проблемы определения признаков насилия в статьях УК РФ
}

\author{
Н.В. Тыдыкова \\ Алтайский государственный университет \\ 656049, Барнаул, пр. Ленина, 61. E-mail: academnauka@rambler.ru
}

Статья посвящена исследованию правового термина «насилие», который не имеет законодательного определения, и по-разному толкуется в научно-исследовательской литературе. Отсутствие определения понятия в диспозициях статей не позволяет в каждом конкретном случае однозначно определить тот объем понятия «насилие», который входит в состав, и тот, который требует дополнительной квалификации. В статье предлагается два способа определения объема понятия. Один из них связан с системным толкованием рассматриваемой нормы, сравнением признаков основного состава и квалифицирующих признаков. Другой способ предполагает сравнение санкции толкуемой нормы с санкциями норм, устанавливающих ответственность за применение насилия спорного объема в чистом виде. Затрагиваются вопросы деления насилия на физическое и психическое и способов фиксирования этих видов в диспозициях норм УК РФ. Исследованием обнаруживается отсутствие единообразия терминологии при закреплении этих признаков в нормах УК РФ. В статье исследуется проблема соотношения терминов «насилие», «принуждение» и «понуждение», используемых в статьях УК РФ в разных значениях, в то время как понятия «принуждение» и «понуждение» целесообразно использовать как синонимы. Критикуется отсутствие официального толкования терминов «насилие, опасное для жизни и здоровья» и «насилие, не опасное для жизни и здоровья» и использование разъяснений, не предусмотренных для данных составов преступлений. Делается вывод о необходимости разработки концепции насилия, предполагающей наличие общего понятия, универсальных терминов, единых классификаций и содержания различных видов и форм его проявления.

Ключевые слова: насилие, принуждение, физическое насилие, психическое насилие, вред здоровью.

Language of Law

\section{Towards the "crime of violence" definition in the Criminal Code of the Russian Federation}

\author{
Tydykova N.V.
}

Altai State University

656049, Barmaul, Lenina st., 61. E-mail: academnauka@rambler.ru

\begin{abstract}
The article is devoted to the study of the term «violence», which has no legislative definition, and in the academic literature is defined in different ways. The absence of definition in the dispositions of articles does not allow to unambiguously determine in each case the amount of violence involved, and which requires additional qualification. The article proposes two ways to determine the amount of violence in different cases. One of them is connected with the systemic interpretation of the norm in question, and the comparison of the characteristics
\end{abstract}


of the elements essential and the qualifying characteristics. Another way is to compare the sanction of the interpreted norm with the sanctions of the norms establishing responsibility for the use of violence of the disputed volume in its pure form. The issue of dividing violence into physical and mental and ways of fixing these types in the dispositions of the norms of the Criminal Code of the Russian Federation is touched upon. The author notes that there is no uniformity of terminology when fixing these elements in the norms of the Criminal Code of the Russian Federation. The article ponders on the problem of the relationship between the terms "violence", "coercion" and "forcing." It is noted that legislators themselves in different norms lay a different meaning in these terms. It is proposed to understand "coercion" and "forcing" as synonyms. The lack of an official interpretation of the terms "violence dangerous to life and health" and "violence not dangerous to life and health" is criticized as well as the use of explanations provided for them. The author concludes that it is necessary to develop the concept of violence, which means the existence of a general concept, universal terms, general classifications and the scope of various types and forms of manifestations.

Key words: violence, compulsion, physical violence, mental violence, harm to health.

УК РФ содержит большое количество составов преступлений, включающих насилие в качестве одного из элементов. В законодательстве нет определения понятия «насилие», в научно-исследовательской литературе также не встречается его общепринятой дефиниции [Гаухман 2014].

Толкование значения слова «насилие» в русском литературном языке является достаточно широким «принудительное воздействие на кого-либо, нарушение личной неприкосновенности» [Ожегов 1992]. Однако словарная статья не может быть взята за основу для определения уголовно-правовой категории насилия, так как дает общее его понятие, не указывая на конкретные признаки, которые позволили бы отграничить его от смежных понятий. Признаки, перечисленные в определении, могут быть взяты лишь за основу исследования правового феномена «насилие». В литературе отмечается, что основное содержание насилия - это действие одного субъекта вопреки желанию другого или принуждение к действиям, совершения которых лицо не желает [Логунова 2006: 217; Сердюк 2002:14; Шарапов 2001: 20]. Таким образом, можно согласиться с общим мнением о том, что насилие - это деяние, совершенное вопреки чьему-то желанию, подавление свободного волеизъявления, навязывание чужой воли [Шарапов 2001: 20].

К сожалению, в уголовном законодательстве отсутствует единообразие при закреплении этого признака в разных составах преступлений. В одних случаях законодатель говорит о применении насилия как такового (ч. 1 ст. 131 УК РФ), в других - конкретизирует объем данного правонарушения (ч. 1 ст. 162 УК РФ), в третьих, - не употребляя понятия «насилие», тем не менее, фактически перечисляет его последствия (п. «а» ч.3 ст. 127.1 УК РФ).

В тех случаях, когда диспозиция нормы содержит указание на объем наступивших последствий от насилия, проблем для квалификации деяний почти не возникает. В тех же случаях, когда формулировка не содержит такой конкретики, бывает непросто определить, какой вид насилия охватывается нормой, а какой требует дополнительной квалификации. Примером такой проблемы может служить ч.1 ст. 131 УК РФ, где закреплен признак насилия, но не определен его объем. Эта проблема может быть решена путем системного толкования нормы. Так как угроза убийством и причинение тяжкого вреда здоровью по неосторожности являются квалифицирующими признаками, а причинение смерти по неосторожности - особо квалифицирующим признаком и совершение деяния при их наличии влечет более строгую ответственность, то в основном составе остается меньший объем насилия - побои, удержание, ограничение свободы, причинение легкого вреда здоровью и вреда здоровью средней тяжести. Соответственно, умышленное причинение тяжкого вреда здоровью и смерти требуют дополнительной квалификации по соответствующим статьям УК РФ. Кстати говоря, такая иерархия насилия не является установленной законом, а скорее условно принята в правоприменительной практике.

Более сложный механизм установления объема насилия, закрепленного в составе, требует п. «а» 4.2 ст. 240 УК РФ, где также указано на применение насилия, но не конкретизирован его объем. В отличие от предыдущей ситуации, здесь насилие входит не в основной состав, а уже в квалифицированный, при это особо квалифицирующих признаков, связанных с насилием, нет. Поэтому применение метода системного толкования здесь не даст положительного результата. Единственным вариантом видится обращение к максимальному пределу санкции нормы и ее сравнение с максимальными пределами санкций норм, устанавливающих ответственность за применение насилия спорного объема в чистом виде. Так, рассматриваемая норма имеет санкцию до 6 лет лишения свободы с ограничением свободы до 2 лет. Менее строгие санкции имеют нормы, предусматривающие уголовную ответственность за умышленное причинение легкого вреда здоровью (ч.1 ст. 115 УК РФ), умышленное причинение вреда здоровью средней тяжести (ч.1 ст. 112 УК РФ), причинение тяжкого вреда здоровью по неосторожности (ч.1 ст. 118 УК РФ). Это позволяет сделать вывод о том, что общественная опасность такого насилия уже учтена при конструировании рассматриваемой нормы. Значит, дополнительной квалификации требует только умышленное причинение тяжкого вреда здоровью потерпевшего (ч.1 ст. 111 УК РФ) и умышленное причинение смерти (ч.1 ст. 105 УК РФ). Такой подход не является законодательно установленным правилом, но поддерживается в науке уголовного права [Кругликов 2015: 73].

Целый ряд проблем вызывает и использование законодателем конструкций «насилие, опасное для жизни или здоровья» и «насилие, не опасное для жизни или здоровья». 
Встречаются такие конструкции достаточно часто: в статьях 126, 126, 161, 162, 166, 206, 211, 221, 226, 229, 296, 309 Уголовного кодекса РФ и ряде других.

Однако сам законодатель нигде не раскрывает, какой конкретно объем насилия охватывается каждой их них. Так как без понимания этого вопроса невозможно и применение указанных норм, то для нужд правоприменительной практики соответствующие разъяснения дал Верховный Суд РФ в Постановлении от 27.12.2002 N 29 «О судебной практике по делам о краже, грабеже и разбое». Хотя это постановление посвящено разъяснению вопросов квалификации только нескольких определенных составов преступлений, в силу отсутствия аналогичных разъяснений по вопросам других составов, предлагаемая в нем трактовка насилия, опасного для жизни или здоровья, и насилия, не опасного для жизни или здоровья, используется правоприменительной практикой для нужд всех составов преступлений, содержащих рассматриваемые конструкции. Возможно, такой механизм толкования содержания терминов и является в настоящее время единственным, однако его сложно признать правильным.

В науке уголовного права насилие традиционно делится на два вида: физическое и психическое. Например, в 4.1 ст. 132 УК РФ отдельно указано насилие (физическое) и угроза его применения (психическое насилие). Однако при закреплении признаков насилия в диспозициях норм законодателем это не всегда учитывается. Например, в п. «в» 4.2 ст. 283.1 УК РФ указано на применение насилия. С учетом того, что в других случаях угроза применения насилия оговаривается отдельно, можно было бы предположить, что если бы законодатель захотел включить этот компонент в состав преступления, то указал бы его. Однако правоприменительная практика идет по пути понимания термина «насилие» как комплексного явления, которое аккумулирует в себе как физический компонент, так и психический (угрозу). Такой подход вполне оправдан, так как в противном случае угроза применения насилия зачастую оказывалась бы за рамками составов насильственных преступлений, являясь, при этом, тоже формой его проявления. Кроме того, тезис о взаимосвязи физического и психического в понятии насилия поддерживается и наукой уголовного права [Крылов 2016: 132].

Наряду с понятием «насилие», в УК РФ законодатель использует такие термины как «принуждение» и «понуждение», не объясняя, каково соотношение этих терминов. Анализ норм, содержащих в качестве элемента объективной стороны принуждение, показал, что сам законодатель в разных нормах закладывает в эти термины разное значение. Из содержания одних норм можно сделать ввод, что принуждение - более широкое понятие, нежели насилие, и наряду с другими категориями включает в себя насилие (например, ст. 120, ст. 149, ст. 179 УК РФ). Из анализа содержания других норм напрашивается вывод, что принуждение - самостоятельная категория, не связанная с насилием (например, ч.2 ст. 142 УК РФ). Отсутствует и источник, который бы содержал официальное толкование этого понятия. Также несколько раз в УК РФ использован термин «понуждение» (примечание к ст. 117, ст. 133, ст. 206 УК РФ). Толкование этого понятия также нигде не встречается, кроме того не ясно, как оно соотносится с термином «принуждение». В литературе обосновывается целесообразность понимания принуждения и понуждения как синонимов [Шарапов 2005:29]. Думается, что можно принять доводы Р.Д. Шарапова и считать рассматриваемые термины синонимами, а следовательно, законодателю необходимо выбрать один из них для использования в нормах УК РФ. В литературе принуждение определяется как незаконное, против воли человека, психическое или физическое воздействие на него с целью заставить совершить определенные действия или воздержаться от их совершения вопреки своей воле [Девятовская 2010: 128]. Так как принуждение или понуждение возможны с применением насилия, то правильно рассматривать насилие как один из способов принуждения.

В литературе по уголовному праву отмечается и проблема соотношения понятия насилия с понятиями «физическое принуждение» и «психическое принуждение» [Цебоев 2016: 71]. Разграничение данных правовых категорий также является перспективой науки уголовного права и законодательной практики.

Сказанное выше позволяет сформулировать вывод о необходимости разработки концепции насилия, предполагающей наличие общего понятия, универсальных терминов, единых классификаций и содержания различных видов и форм проявлений. Это позволит создать понятную и непротиворечивую систему насильственных преступлений в УК РФ.

\section{Литература}

1. Гаухман Л.Д. Проблемы квалификации насильственных преступлений / Уголовное право. - 2014. - № 5.

2. Девятовская, С. В. Понятие принуждения в российском уголовном праве / Юристъ-Правоведъ. - 2010. - № 2.

3. Кругликов Л.Л. О понятии и уголовно-правовой оценке насилия / Уголовное право. - 2015. - № 1.

4. Крылов Н.Г. К вопросу о содержании понятия «насилие» в российском уголовном праве / Вестник саратовской государственной юридической академии. - 2016. - № 5 (112).

5. Логунова О.С. Насилие и его формы в ст. 117 УК РФ и ст.302 УК РФ / Современные вопросы государства, права, юридического образования: материалы III Общероссийской научно практической Интернет-конференции / отв.ред. О.В. Белянская. Тамбов, 2006.

6. Ожегов С.И., Шведова Н.Ю. Толковый словарь русского языка. М., 2006.

7. Сердюк Л.В. Насилие: криминологическое и уголовно-правовое исследование. М., 2002.

8. Фокин М.С. Содержание понятия «насилие» по действующему уголовному законодательству / Вестник Омского университета. Серия Право. - 2010. - № 3 (24). - С. 159-162.

9. Ц Цебоев А.П. Насилие как признак преступного поведения и проблемы его регламентации в нормах российского 
уголовного закона / Вестник краснодарского университета МВД России. - 2016. - № 1 (31).

10. Шарапов Р.Д. Теоретические основы квалификации насильственных преступлений. Тюмень, 2005.

11. Шарапов Р.Д. Физическое насилие в уголовном праве. СПб., 2001.

\section{References}

1. Ceboev, A.P. (2016). Nasilie kak priznak prestupnogo povedeniya i problemy ego reglamentacii v normax rossijskogo ugolovnogo zakona. Vestnik krasnodarskogo universiteta MVD Rossii, 1(31) (in Russian).

2. Devyatovskaya, S. V. (2010). Ponyatiye prinuzhdeniya v rossiyskom ugolovnom prave. Yurist-Pravoved, 2 (in Russian).

3. Fokin, M.S. (2010). Soderzhanie ponyatiya "nasilie" po dejstvuyushhemu ugolovnomu zakonodatelstvu. Vestnik Omskogo universiteta. Seriya Pravo, 3(24), 159-162 (in Russian).

4. Gauxman, L.D. (2014). Problemy kvalifikacii nasilstvennyx prestuplenij. Ugolovnoe pravo, 5 (in Russian).

5. Kruglikov, L.L. (2015). O ponyatii i ugolovno-pravovoj ocenke nasiliya. Ugolovnoe pravo, 1 (in Russian).

6. Krylov, N.G. (2016). K voprosu o soderzhanii ponyatiya «nasilie» v rossijskom ugolovnom prave. Vestnik saratovskoj gosudarstvennoj yuridicheskoj akademii, 5(112) (in Russian).

7. Logunova, O.S. (2006). Nasilie i ego formy v st. 117 UK RF i st. 302 UK RF. Sovremennye voprosy gosudarstva, prava, yuridicheskogo obrazovaniya. Proceed. III All-Russian Sc. Internet Conf. Tambov (in Russian).

8. Ozhegov, S.I., Shvedova, N.Yu. (2006). Dictionary of the Russian Language. Moscow (in Russian).

9. Serdyuk, L.V. (2002). Nasilie: kriminologicheskoe i ugolovno-pravovoe issledovanie. Moscow (in Russian).

10. Sharapov, R.D. (2001). Fizicheskoe nasilie v ugolovnom prave. Saint Petersburg (in Russian).

11. Sharapov, R.D. (2005). Teoreticheskie osnovy kvalifikacii nasilstvennyx prestuplenij. Tyumen (in Russian).

\section{Citation:}

Тыдыкова Н.В. Проблемы определения признаков насилия в статьях УК РФ // Юрислингвистика. - 2019. - 11. - С. 11-14.

Tydykova, N.V. (2019). Towards the "crime of violence" definition in the Criminal Code of the Russian Federation. Legal Linguistics, 11, 11-14.

(cc) EY This work is licensed under a Creative Commons Attribution 4.0. License 